\title{
SASADU: ARSITEKTUR TRADISIONAL JAILOLO HALMAHERA BARAT
}

\author{
SASADU, ARCHITECTURE OF JAILOLO OF WEST HALMAHERA
}

\author{
Mezak Wakim \\ Balai Pelestarian Nilai Budaya Ambon \\ Jln. Ir. M. Putuhena Wailela Poka Rumahtiga Ambon \\ e-mail : wakimmezak@gmial.com
}

\begin{abstract}
Abstrak
Penelitian ini mengkaji arsitektur tradisional masyarakat Jailolo, yakni rumah adat sasadu. Rumah adat ini merupakan tempat dilaksanakannya ritual masyarakat Jailolo Halmahera Barat. Rumah adat sasadu berlokasi di Desa Taraudu, Kabupaten Halmahera Barat. Konstruksi rumah adat sasadu didirikan langsung di atas tanah. Bangunan ini berbentuk bidang geometris empat persegi panjang yang mencerminkan bentuk kebudayaan masyarakat Jailolo pada masa lalu. Tujuan penelitian ini adalah mengungkap bentuk dan fungsi ruang, struktur bangunan, ragam hias, dan kosmologi dalam asrsitektur sasadu. Metode penelitian yang digunakan bersifat deskriptif dengan pendekatan kualitatif. Teknik pengumpulan data berupa wawancara, pengamatan, dan studi pustaka. Hasil peneltian menunjukkan bahwa bangunan sasadu berbentuk bidang geometris empat persegi panjang yang terbagi atas susunan antara lain (1) Ruang tengah; (2) Ruang samping, dengan susunan konstruksi atas terdiri atas atap samping dengan kemiringan rendah berpaut pada pinggir atas ruang tengah yang bersudut atap lancip. Letak bangunan arah timur-barat. Sasadu terdiri atas susunan atas dengan kemiringan rendah memiliki atap tengah berbentuk segi tiga sama kaki yang tinggi lancip. Dapat disimpulkan bahwa sasadu memiliki tipologi geometris dalam bentuk empat persegi, dengan susunan atap lancip berbentuk segi tiga dan hiasan najung perahu pada kedua puncak ujung bubungan yang mencerminkan falsafah hidup masyarakat Jailolo pada umumnya.
\end{abstract}

Kata kunci : sasadu, arsitektur Jailolo, najung perahu.

\section{Abstract}

This study examines the traditional architecture of Jailolo society, namely custom house Sasadu. This house is a ritual execution of public Jailolo West Halmahera. Sasadu custom house is located in the village Taraudu, West Halmahera. Sasadu custom house construction erected directly on the ground. The building shaped are rectangular field of geometric shapes that reflect the culture of the people Jailolo in the past. The purpose of this study is to reveal the shape and function space, structure, decoration, and cosmology in Sasadu architecture. The method of the research is descriptive with qualitative approach. Data collection techniques such as interviews, observation, and literature. Research findings show that the building of Sasadu are geometric shaped rectangular field that is divided into the composition include (1) Living room; (2) side room, with a composition consisting of a roof construction on the side with the lower slope of the interlock on the upper edge of the angled roof of the living room taper. The layout of the building are east-west direction. Sasadu consists of arrangement on the lower slope of the roof of the center has an isosceles triangular taper high. It can be concluded that Sasadu have geometric typology in the form of a square, with a pointed roof arrangement and triangular decoration najung boat on both ends of the ridge crest which reflects the philosophy of life of Jailolo society in general.

Keywords: sasadu, architecture, Jailolo, najung perah. 


\section{A. PENDAHULUAN}

Arsitektur tradisional adalah salah satu hasil kebudayaan yang dimiliki oleh bangsa Indonesia. Tradisi mendirikan sebuah bangunan disadari atau tidak merupakan sebuah tradisi berarsitektur yang telah dilakukan oleh suku-suku bangsa yang ada di Indonesia sejak zaman dahulu. Arsitektur pada suatu suku bangsa selalu berhubungan dengan kepercayaan yang dianut, berhubungan dengan iklim dan kondisi alam setempat serta mata pencaharian mereka (Purwestri, 2007: 1).

Arsitektur tradisional di

Halmahera Barat, khususnya di Jailolo, pada saat ini masih ditemukan di beberapa tempat atau desa. Namun demikian apabila tidak dirawat secara baik lama kelamaan mengalami kepunahan. Masuk dan berkembangnya pengaruh budaya dari luar dan kemajuan ilmu pengetahuan dan teknologi yang serba cepat, telah pula mengaburkan kaidah-kaidah arsitektur tradisional di Maluku. Sebagai masyarakat kepulauan di Maluku, arsitektur bangunan ataupun ragam hiasnya seringkali melambangkan perahu. Unsur perahu muncul dengan sangat jelas pada bangunan tradisional di Halmahera dan Kepulauan Maluku Tenggara. Sedangkan unsur-unsur persekutuan patasiwa patalima lebih menonjol pada bangunanbangunan komunal di Maluku Tengah (Seram dan Lease). Dilihat dari segi ragam hias pada bangunan, maka secara umum menampakkan motif matahari, flora dan fauna serta simbol-simbol yang berhubungan dengan kesuburan dan pemujaan terhadap arwah leluhur.

Secara fisik bentuk keaslian arsitektur yang khas dapat memotivasikan nilai-nilai jati diri dari suatu kelompok etnis tentang latar belakang sejarah budayanya. Hal tersebut dapat dilihat dari arsitektur bagian luar bangunan yang mengandung gaya tipologi dengan penampilan karakter bentuk ciri-ciri khusus yang menonjolkan simbol-simbol identitas suatu kelompok etnis. Dari segi fungsinya, bangunan tradisional sasadu, mempunyai tata ruang yang berfungsi sebagai wadah yang didasarkan pada norma-norma yang mengandung falsafah bagi pembentukan karakter dan kepribadian. Bangunan sasadu mengisyaratkan nilai-nilai aturan, tata krama antarkeluarga, hubungan sosial antarmasyarakat, saling menghargai dan menghormati bagi terciptanya kerukunan dan keharmonisan hidup atas dasar kebersamaan. Rumah tempat musyawarah sasadu ini digunakan sebagai pusat upacara panen, tempat menyelesaikan adat, tempat musyawarah. Kosmologi orang Sahu di Taraudu, berpangkal dari rumah adat dimaksud. Secara fisik sasadu dibangun dengan sistem konstruksi rangka bahan sederhana, namun memiliki makna penting bagi orang Sahu- Jailolo (Joseph \& Rijoli, 2005: 49).

Dalam tradisi masyarakat Jailolo ditemukan relevansi antara lingkungan dan kehidupan budaya manusia. Tata cara pembuatan rumah juga terwujud dari penggambaran konsep arsitektur tradisional sasadu. Wujud konstruksinya memberi petunjuk akan fungsi sasadu sebagai representasi adat dan budaya masyarakat yang meliputi tata cara menentukan lokasi rumah, menentukan arah orientasi rumah, dan penyelenggara adat di dalam rumah serta upacara ritual dalam mendirikan rumah. Rangkaian tata cara adat ini merupakan keterpaduan dari simbol kehidupan yang digambarkan dalam konsep arsitektur sasadu. Perkembangan arsitektur moderen pada prinsipnya memberi gaya tersendiri dari tawaran nilai yang memengaruhi adanya keberadaan arsitektur tradisional sasadu. Di Jailolo Kabupaten Halmahera Barat kini konsep arsitektur tradisional moderen mengucilkan keberadaan sasadu sebagai simbol utama rumah tradisional masyarakat Jailolo. Adanya bangunanbangunan yang megah, kini bukan saja menghiasi perkotaan besar namun memengaruhi kehidupan masyarakat di Desa Taraudu, Kabupaten Halmahera Barat. 
Rumah adat arsitektur sasadu merupakan warisan budaya masyarakat Jailolo pada umumya dalam memperkokoh ketahanan budaya bangsa. Oleh karena itu perlu dilakukan sebuah kajian mendalam yang berhubungan dengan arsitektur tradisional sasadu. Dalam realitas kebudayaan tentunya arsitektur tradisional sasadu merupakan simbol kejayaan kebudayaan masyarakat Jailolo yang pada waktu itu berhubungan erat dengan Kerajaan Jailolo sebagai satu dari kesultanan di Maluku Utara. Pokok permasalahan yang muncul dari penelitian ini adalah : 1) Bagaimana konsep arsitektur tradisional sasadu; 2) Bagaimana bentuk dan konstruksi sasadu; 3) bagaimana fungsi ruang dalam konsep sasadu; 4) Bagaimana bentuk ritual awal membangun sebuah arsitektur sasadu dan ritual akhir pembangunan sasadu.

Tujuan penelitian ini adalah untuk mengungkap dan mendeskripsikan konsep arsitektur sasadu yang berhubungan dengan bentuk, makna dan fungsi sasadu dalam kebudayaan masyarakat Jailolo Halmahera Barat. Ruang lingkup penelitian juga meliputi dual hal yakni wilayah dan materi. Ruang lingkup wilayah penelitian adalah di Desa Taraudu Jailolo, Kabupaten Halmahera Barat. Sedangkan ruang lingkup materi terdiri atas: konsep sasadu dalam kebudayaan masyarakat Jailolo, arsitektur sasadu yang meliputi konstruksi bangunan, ruang, fungsi, ragam hias, dan kosmologi sasadu.

\section{B. METODE PENELITIAN}

Penelitian ini menggunakan metode deskriptif dengan pendekatan kualitatif tentang arsitektur sasadu. Data yang di kumpulkan menggunakan data primer dan sekunder. Adapun teknik pengumpulan data dilakukan antara lain :

\section{Pengamatan (0 bservasi)}

Pengamatan dilakukan secara langsung di lapangan pada hal yang berhubungan dengan model dan gaya arsitektur sasadu. Unsur-unsur yang diamati secara langsung meliputi bangunan, termasuk cara pembuatan bangunan sasadu, fungsi dan makna bangunan sasadu dalam kehidupan masyarakat Jailolo pada umumnya.

\section{Wawancara}

Wawancara dilakukan dengan menyiapkan pedoman wawancara yang telah disusun dan berorientasi pada pokokpokok masalah yang akan diteliti. Metode wawancara yang digunakan adalah wawancara mendalam (indepth intervieuw) kepada informan atau ketua adat dan tooj masyarakat yang lebih mengetahui bangunan tradisional arsitektur sasadu. Melalui wawancara mendalam diharapkan dapat terkumpul data mengenai nilai dan makna simbolis dari setiap ragam hias dan ruang serta berbagai informasi yang berhubungan dengan arsitektur tradisonal sasadu.

\section{Studi Kepustakaan}

Studi kepustakaan ini dilakukan dengan cara mengkaji tulisan-tulisan dan berbagai konsep serta berbagai literatur lainnya yang berkaitan dengan masalah penelitian.

\section{A nalisis Data}

Tahapan ini merupakan tahap paling akhir yang dilakukan setelah data berhasil dikumpulkan mulai dari penentuan lokasi, pengamatan dan wawancara, serta studi kepustakaan yang berkaitan dengan masalah yang diteliti. Hasil tersebut diolah dan disusun sehingga menjadi sebuah laporan dan merupakan bagian dari rangkaian suatu penulisan ilmiah.

\section{HASIL DAN BAHASAN \\ 1. Pengertian Sasadu}

Sasadu secara etimologi berasal dari kata sadu, yang dalam bahasa Sahu tidak mempunyai arti, sedang dalam bahasa Ternate sadu berarti menimba, dan sado berarti lengkap, genap bilangannya. Istilah lain untuk rumah musyawarah di Sahu adalah kagunga, yang berarti rumah dengan empat pintu. Istilah tersebut digunakan untuk menekankan oposisi 
kosmologi antara kagunga tagi-tagi. Yang dimaksud di sini adalah perahu dan kagunga tego-tego atau perahu yang tidak mengapung adalah sasadu itu sendiri. Kata lain yang sama adalah batangan, yang sebenarnya adalah bangunan yang terdapat di bawah atap. Dalam hal sasadu, istilah sabua dalam bahasa Melayu Maluku bisa berarti atap yang ada pada perahu-perahu tradisional di sana, atau atap rumah adat di desa (Marsadi, 1980: 386).

Masyarakat di Desa Taraudu di Kecamatan Sahu menyebut rumah tempat musyawarah mereka dengan nama sasadu artinya rumah yang besar dalam desa atau sabua saja. Sedangkan masyarakat di desadesa lainnya menyebut semua rumah yang ada dalam desa sebagai sasadu. Dapat disimpulkan bahwa sasadu adalah rumah pertama dari semua rumah yang dibangun pada suatu lokasi perkampungan. Dalam perkembangan selanjutnya, sasadu itu menjadi tempat berkumpulnya semua keluarga di dalam kampung untuk bermusyawarah. Walaupun mereka berasal dari pedalaman namun sasadu menyimbolkan sebuah perahu. Ini tampak jelas melalui hiasan pada kedua manumata sasadu yang melengkung ke atas menyerupai najung perahu (Joseph \& Rijoli, 2005 : 12).

Lokasi arsitektur tradisional sasadu berada di Desa Taraudu, yakni sebuah desa tua yang letaknya kurang lebih $17 \mathrm{~km}$ dari ibu kota Kabupaten Jailolo. Dari perspektif sejarah perjalanan masyarakat sampai pada akhirnya membangun dan menetap di Desa Taraudu relatif cukup panjang. Dari informasi yang diterima oleh tua-tua adat diketahui bahwa para leluhur berpindahpindah sampai delapan kali dari satu tempat ke tempat lain, baru akhirnya memutuskan menetap di Desa Taraudu ini. Tara artinya tunduk dan $u d u$ artinya bulu atau bambu. Jadi taraudu artinya batang pohon bambu yang sedang merunduk. Masyarakat yang tinggal di Kecamatan Sahu berasal dari dua suku bangsa, masing-masing suku Talaie dan suku Padi Sua. Selanjutnya keturunan dari dua suku bangsa ini menyebar ke desa-desa yang ada di Kecamatan Sahu. Masing-masing adalah suku Talaie menyebar ke Desa Worat-Worat, Golo, Tamome, Balesoan, Idam dan Desa Loceua. Sedangkan suku bangsa Padi Sua menyebar antara lain ke DesaTaraudu, Awer, Akelamo, Aketola, Padosoa, Tibobo, Hokogama, Ngapanyira, Gamnyial, Campaka, Gamsungi. Walaupun mereka tinggal terpisah-pisah, pada umumnya mereka memiliki adat dan budaya yang sama.

Mengenai asal mula leluhur masyarakat sampai di Desa Taraudu sekarang ini kemudian bermukim dapat dikemukakan sebagai berikut. Dahulu ada sebuah keluarga yang tinggal di Wisil. Saat terjadi perang antarsuku, keluarga tersebut berpindah ke daerah lain yang disebut Gamsungi. Di sini keluarga tersebut bergabung dengan beberapa keluarga yang lain. Untuk beberapa lama keluargakeluarga tersebut menetap untuk berburu, namun selanjutnya mereka akhirnya berpindah-pindah lagi dan membangun tempat tinggal yang baru, yakni di Tarau, Kutor, Gamurako, Kota-kota, Gampale dan akhirnya menjadi kelompok masyarakat yang cukup banyak dan menetap di tempat yang sekarang dinamakan Taraudu. Saat itu kampung tempat tinggal penuh dengan pohon bambu yang melambai-lambai ditiup angin seperti merunduk. Setelah memutuskan untuk menetap di Desa Taraudu, penduduk desa dan penduduk dari desa-desa lain di sekitarnya yang berasal dari dua suku bangsa yang dikemukakan di atas, menanam padi sebagai pekerjaan utama mereka. Padi-padi yang dihasilkan dari desa tersebut sangat baik dan cukup banyak. Lama-kelamaan kelezatan padi dari desa-desa tersebut sampai ke telinga Sultan Ternate pun Sultan menjadikan masyarakat yang tinggal di desa-desa dalam Kecamatan Sahu sebagai lumbung makanan atau dapur kerajaan keluarga Sultan. Adapun orangorang Makian atau orang-orang dari Mara disebut sebagai orang-orang depan, yang siap menerima tamu. 
Kecamatan Sahu, pada mulanya bernama Desa Su Wu Wu u. Setiap habis panen, masyarakat yang telah mengumpulkan hasil panen padi di $\mathrm{Su} \mathrm{Wu}$ $\mathrm{Wu} \mathrm{u}$ datang ke istana Sultan untuk menyerahkan makanan. Biasanya mereka tiba saat Sultan sedang sa ur. Oleh karena itu Sultan menamakan mereka sebagai orang-orang sa ur dan lama kelamaan menjadi orang-orang Sahu. Oleh karena itu ada ungkapan tradisional yang sampai sekarang dikenal oleh orang-orang Sahu yaitu masulabi kie mara mahuto kie sahu artinya di bagian muka atau depan itu adalah orang-orang dari Pulau Makian atau Pulau Mara sedangkan bagian dapur adalah orang-orang dari Sahu. Pada masa pemerintahan ayahanda Sultan Ternate yang sekarang Sultan Mudafar Syah yakni Sultan Djabir Syah, beliau pernah bermalam di Desa Taraudu ketika melakukan tugas berkunjung ke desa-desa dalam wilayah kerajaannya. Sultan bermalam di rumah sasadu yang dibangun pada 1931 yang sekarang ini berusia kurang lebih 76 tahun. Dinding-dinding rumah sasadu yang semula terbuka secara tiba-tiba ditutup dengan cara menggantungkan daun-daun atap agar Sultan dapat tidur dengan tenang. Menurut informasi dari tetua adat yang sempat pula melayani Sultan ketika Sultan diturunkan dari tandu atau usungan, ia tidak diizinkan menginjak tanah tetapi digendong oleh masyarakat dari tangan ke tangan sebagai bukti betapa besar rasa hormatnya masyarakat terhadap sultan mereka.

\section{Tipologi Sasadu}

Rumah musyawarah sasadu merupakan salah satu sarana penting yang merupakan simbol masyarakat adat di Kecamatan Sahu. Di tempat ini berlangsung seluruh aktivitas masyarakat yang berkaitan dengan adat istiadat, seperti musyawarah untuk membuka kebun baru, panen serta penyelesaian sengketasengketa adat lainnya. Untuk itu pembangunan rumah musyawarah sasadu harus mengikuti tata aturan adat yang telah ada sejak dahulu.
Bentuk bangunan sasadu yang didirikan di atas tanah memiliki denah berbentuk bidang geometris empat persegi panjang yang terbagi atas susunan antara lain (1) Ruang tengah berbentuk empat persegi panjang dengan delapan tiang utama; (2) Ruang samping yang mengelilingi ruang tengah berbentuk sudut 8 yang ditopang dengan 12 tiang pinggir luar dan 12 tiang tengah antara tiang luar dan tiang induk ruang tengah; (3) Susunan konstruksi atas terdiri atas atap samping dengan kemiringan rendah berpaut pada pinggir atas ruang tengah yang bersudut atap lancip; (4) Letak bangunan arah timur-barat, sasadu terdiri atas susunan atas dengan kemiringan rendah memiliki atap tengah berbentuk segi tiga sama kaki yang tinggi lancip. Dapat disimpulkan bahwa sasadu memiliki tipologi geometris dalam bentuk empat persegi, dengan susunan atap lancip berbentuk segi tiga dan hiasan najung perahu pada kedua puncak ujung bubungan (lihat gambar di bawah ini).

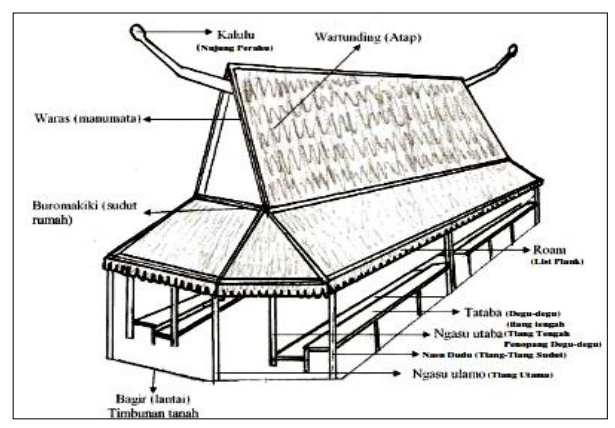

Gambar 1. Sketsa Arsitektur Sasadu Sumber: Peneltian 2007

Pada gambar sketsa di atas terlihat jelas bagian-bagian dari sasadu yang dimunculkan sebagai satu kesatuan dari totalitas bangunan sasadu.

\section{Konstruksi Sasadu a. Konstruksi Bangunan Bawah}

Sasadu memiliki lantai dasar yang terdiri atas timbunan tanah yang dipadatkan. Agar tanah tidak berserakan keluar maka pinggiran tanah ditahan oleh 
susunan batu kali membentuk sudut 8 . Timbunan lantai dasar ini lebih tinggi kirakira 30 s.d. $40 \mathrm{~cm}$ dari halaman luar bangunan yang disebut bangir. Pada bangir diletakkan dasar-dasar tumpuan tiang batu yang tertanam separuhnya pada dasar lantai yang terdiri atas 8 buah dasar tiang induk ngasu lamo, 12 tumpuan tiang samping luar ngasu $u$ dudu dan 12 buah tiang tengah ngasu u taba.

\section{b. Konstruksi Bangunan Tengah}

Fungsi sasadu sebagai tempat musyawarah tidak berdinding. Tiangtiang tidak ditanam dalam tanah tetapi dialas dengan batu. Tiang-tiang tersebut antara lain adalah :

- Ngasu u lamo yaitu 8 buah tiang induk yang ada pada sentral bangunan. Tiang-tiang ini lebih besar daripada tiang-tiang lain,

- Ngusu u dudu yaitu tiang-tiang samping bangunan yang terletak di sepanjang pinggiran luar yang membentuk 8 sudut yang berjumlah 12 buah. Tiang-tiang ini lebih pendek dan lebih kecil daripada ngasu u lamo, berfungsi sebagai penopang kerangka konstruksi atap miring.

- Ngasu u taba terdiri atas 12 tiang yang terletak antara ngasu u lamo dan ngasu $u$ dudu. Selain berfungsi sebagai penopang konstruksi rangka atas bersama ngasu u dudu, ngasu $u$ taba berfungsi sebagai penopang tengah pertama impitan lantai duduk degu-degu dari lama ngibon dan lama saee. Sedangkan ujung-ujung ruangan ngasu $u$ taba dan ngasu $u$ $d u d u$ menopang degu-degu atau yang disebut lamaa sae pada masing-masing sisi ujung ruangan timur dan barat.

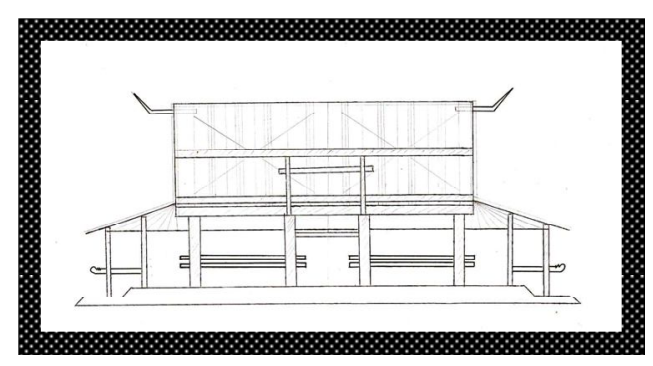

Gambar 2. Rumah Sasadu Tampak Bagian Tengah

Sumber: Penelitian 2007

\section{c. Konstruksi Bangunan Atas}

Pada umumnya sasadu tidak berloteng dan suluh ruangan konstruksi atas terbuka dan dinilai dari pasangan balik yang disebut di ngasu. Di ngasu terdiri atas 4 buah balok yang masingmasing ujungnya terpasok pada sepasang kepala tiang ngasu u lamo. Pada ujungujung lidah balok yang keluar dari masingmasing kepala tiang ngasu $u$ lamo dipasang balok gidang, memanjang dari kiri ke kanan yang mengapit ke-8 tiang utama ngasu u lamo memanjang bangunan. Pada gidang terletak pangkal kasau (toratora) rangka atap samping. Pada ke-4 balok di ngasu masing-masing di atasnya terpancang dua buah tiang ngasu sesera. Pada ujung-ujung atas 8 ngasu sesera masing-masing pasang memiliki ujungujung lidah pasok untuk menopang satu balok baal tala. Selanjutnya pada masingmasing pertengahan patok baal tala dipancang sebuah ngasu $u$ olan sebagai tiang nok. Ke-4 puncak ngasu $u$ olan dihubungkan dengan sebuah balok panjang sebagai penopang ujung-ujung tora-tora sebagai puncak bangunan sasadu. Kemudian pada ujung-ujung balok baal tala yang untuk bagian kiri dan kanannya dihubungkan dengan gidang untuk pemasangan pertengahan kasau tora-tora penutup atap dari bangunan atas. Ada tiga jenis pemasangan atap pada sasadu:

(1) Atap samping utara dan selatan atau muka dan belakang terdiri atas 7 susunan lembaran atap yang disebut wartunding yang ditutup mulai dari kiri ke kanan 
teritis, berjumlah 7 sambungan. Susunan ini berjumlah tetap, tersusun sampai ke atas bubungan; (2) Susunan atap samping timur dan barat dimulai dari teritis dari 4 susunan, tiap baris naik sampai ke atas manumata dan seterusnya menyudut ke puncak bungan-bungan timur dan barat disebut waras; (3) Susunan atap pada ke-4 sudut rumah yang terpancang dimulai dari teritis menuju ke atas disebut buromakiki (menyerupai ekor udang).

Sistem menutup atas pada sasadu, dimulai dari baris teritis kiri ke kanan pada masing-masing sisi dengan ujung atap kanan menutup ujung kiri atap sambungan berikut dan seterusnya. Jarak pemasangan tora-tora atau kasau antara 50 sampai dengan $60 \mathrm{~cm}$. Sesuai dengan panjang bangkawang atau tulang bambu atap dari bawah ke atas antara $15 \mathrm{~cm}$ disebut nalgoan. Pada ujung kasau, bawah teritis dipasang batang kulit pinang selebar 10-15 cm dengan lengkung ke arah luar sebagai lesplang disebut roam. Pada pemasangan atap teritis digunakan 2 lembar lapis atap, yang dialas oleh 2 belahan bambu. Yang menarik adalah pemasangan 2 bilah bambu diikat dengan bentuk hiasan jajaran genjang dengan bahan tali ijuk. Ikatan ini dimulai dari teritis pintu depan sasadu menyambung mengelilingi teritis bangunan, kembali dan berakhir pada tempat dimulainya ikatan tersebut.

Bagian-bagian lain yang menarik dari sasadu adalah adanya simbol perahu pada ke-2 ujung wanata timur dan barat, bentuk ini disebut haluan dan buritan. Bentuk perahu erat sekali kaitannya dengan pemujaan nenek moyang atau leluhur mereka yang datang dari jauh dengan naik perahu dan juga ada kepercayaan perahu adalah kendaraan roh ( Suantika , 2005: 7)

Di Maluku Tenggara tepatnya di Kepulauan Kei, Aru, Tanimbar, dan Babar, perahu bukan hanya sarana angkutan tetapi juga mempunyai arti yang lain. Di daerah ini rumah tempat tinggal dan desa dianggap sebagai perahu, sedangkan penduduk acapkali menganggap dirinya sebagai awak kapal dan penumpang. Mereka menyamakan perahu mereka sebagai manusia. Seperti manusia, perahu terdiri atas unsur laki-laki dan perempuan, dalam pembuatan perahu digunakan juga penggabungan kedua unsur tersebut. Di dalam diri manusia kekuatan hidup yang terpancar dari tubuh dan jiwa mereka, merupakan bagian penting. Di Babar (Dawerlor) rumah adat dianggap sama dengan perahu, yang berlayar sejalan dengan arah matahari, yaitu dari timur ke barat. Para penghuni rumah adat tersebut menamakan diri mereka bergantung pada letak kamar mereka di dalam rumah adat, yaitu sebagai juru mudi atau mualim. Lambang perahu juga digunakan sebagai simbol kesuburan, selain itu lambang ini juga mempunyai peranan pada saat seseorang memenggal kepala musuhnya dan kemudian membawanya pulang sebagai hasil kemenangan (De Jonge \&Toos van Dijk, 1995:146 ).

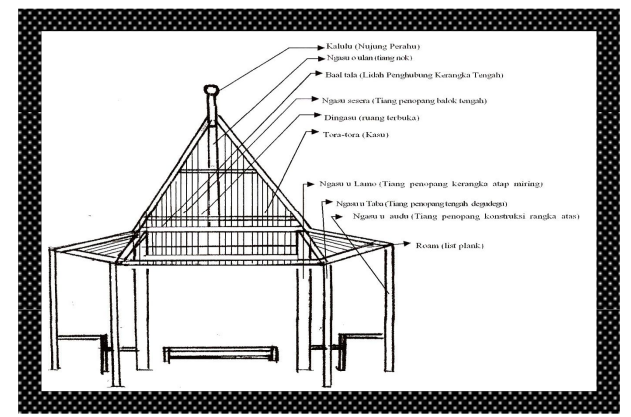

Gambar 3. Rumah Sasadu tampak dari depan (terutama manumata yang melambangkan perahu). Sumber : Penelitian 2007

\section{Fungsi Ruangan}

Ruangan pada sasadu tidak berdinding terbuka atau tidak ada sekat memisahkan ruang satu dari yang lainnya. Namun ada tempat tertentu yang sudah dibuat sesuai dengan fungsinya masingmasing pada saat dilaksanakan upacara. Pada saat upacara, yang hadir di sasadu hanyalah kaum laki-laki dan perempuan yang menjadi wakil klen-klen yang paling terkemuka dalam kelompok Walasae, Ngowarepe, Walangatom dan sebagainya, yang juga dianggap sebagai tuan tanah di 
sana. Tempat duduk mereka diatur menurut keanggotaan dalam salah satu klen melalui garis keturunan laki-laki (patrilineal), dan menurut posisi (kedudukan) hirarkhis klennya dalam kelompok-kelompok teritorial yang lebih besar (garan), seperti Walasae.

Di Sahu, posisi klen selalu digambarkan dengan cara demikian, dan seseorang yang dianggap mewakili nenek moyangnya (omenge) menempati bangku nenek moyangnya dulu. Kadang-kadang pada bilah-bilah atap sasadu yang ada di atas tempat duduk (aoto) para wakil tadi terdapat ukiran garis silsilah nenek moyangnya. Para wanita mengambil tempat duduk sesuai dengan kedudukan suami atau ayahnya. Apa yang biasanya disebut sebagai tradisi atau adat di sini tidak lain adalah konsep-konsep mengenai keteraturan kosmologis yang ada dalam berbagai bagian dalam kebudayaan Sahu yang diwujudkan misalnya dalam kode-kode tertentu yang berkaitan dengan ruang.

Mengenai anggota klen selama upacara di rumah adat, ada "oposisi" antara walasae sebagai adik dan ngowarepe sebagai kakak. Kalau kita perhatikan tempat duduk wakil dari berbagai klen dalam sasadu, kita lihat bahwa anggota garan walasae berada pada posisi laut dan menghadap ke darat, yang juga disebut bagian atas (sasa'du toma relu) sedang anggota-anggota dari ngowarepe duduk berhadapan dengan walasae pada sisi darat dan menghadap ke laut. Urutan klen-klen dalam garan walasae misalnya, berderet pada meja di atas ke bawah, yaitu dari arah laut ke darat. Terlepas dari "oposisi" antara kelompok-kelompok tersebut, ada "oposisi" lain yang lebih universal, yaitu antara peserta laki-laki dan perempuan. Sasadu ini dibagai menjadi dua bagian dengan selembar kain merah putih yang melintang pada sasadu (gelo) dan genderang-genderang besar yang digantungkan di tengah-tengah sasadu.

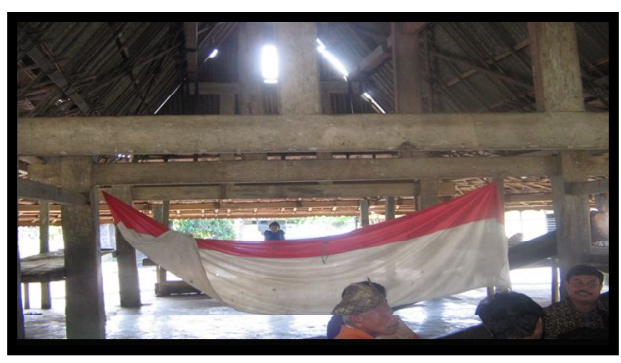

Gambar 4. Gelo (Kain Merah Putih) Sumber :Mezak Wakim 2007

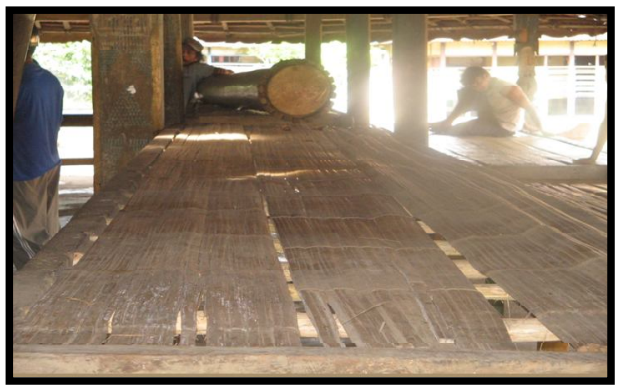

Gambar 5. Tifa Besar (Genderang Besar di Sasadu)

Sumber: Mezak Wakim 2007

Tempat laki-laki adalah sisi 'laut' (pada arah laut) dan perempuan dari sisi 'darat' (pada arah darat). Ini dapat dilihat pada skema berikut ini:

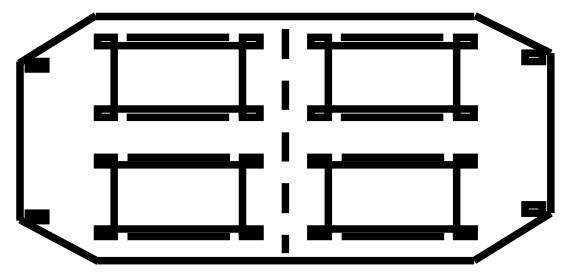

Gambar 6. Skema Posisi/Kedudukan Masyarakat dalam Sasadu

Sumber :Mezak Wakim 2007

Dalam skema, "oposisi-oposisi" ini dapat digambarkan sebagai berikut:

A1 : Walasae, pria, orang-orang tua pada meja utama yang disebut taba sae'e 'meja kepala'. Kelompok walasae dianggap penjaga rumah dan tanah dan diasosiasikan dengan adik, sehingga kedudukannya berhadapan dengan 'darat', yaitu pada sisi laut. 
B1 : Ngowarepe dan garan lain ; pria, orang-orang tua, pada taba ngiman 'meja ketua'. Kelompok ngowarepe berfungsi sebagai kapitan laut dan diasosiasikan dengan kakak, sehingga kedudukannya menghadap ke laut.

A1 dan B1 sebagai bagian laki-laki pada arah laut diasosiasikan dengan bagian 'atas' sasadu.

C1 : Walasae, wanita, orang-orang tua, di meja utama taba sae'e. wanita sebagai pengikut laki-laki diasosiasikan dengan adik, darat.

D1 : Ngowarepe dan garan lain, perempuan, orang-orang tua, pada taba ngimon diasosiasikan dengan laki-laki (B1), jadi kakak dan laut. Bagian perempuan ( $\mathrm{C} 1$ dan $\mathrm{D} 1)$ dianggap sebagai darat atau 'bawah' dalam "oposisi" dengan bagian laki-laki.

Orang-orang tua duduk di sepanjang sisi luar meja, pada bangkubangku yang tinggi (dedegu), sedang anakanak muda (tubayie) menurut hierarki berdiri di sisi dalam meja. Dengan demikian "oposisi" antara yang lebih tua dan lebih muda dalam arti genealogis diwujudkan menjadi "oposisi" dalam tempat antara tinggi: rendah dan luar: dalam. Dalam skema, transformasi ini bisa digambarkan sebagai berikut: $(\mathrm{A} 1-\mathrm{A} 2)=$ $(\mathrm{B} 1-\mathrm{B} 2)=(\mathrm{C} 1-\mathrm{C} 2)=(\mathrm{D} 1-\mathrm{D} 2)$.

Perbedaan status yang ada di antara mereka juga tampak dalam pakaian yang mereka kenakan. Pada umumnya pada malam hari, orang-orang tua baik pria maupun wanita berpakaian warna gelap yang rapi. Kebanyakan biru tua atau hitam. Para pemuda mengenakan pakaian warna terang dengan saputangan yang melingkar di kepala merah kuning dan dipasangi bulu-bulu ayam berwarna putih.

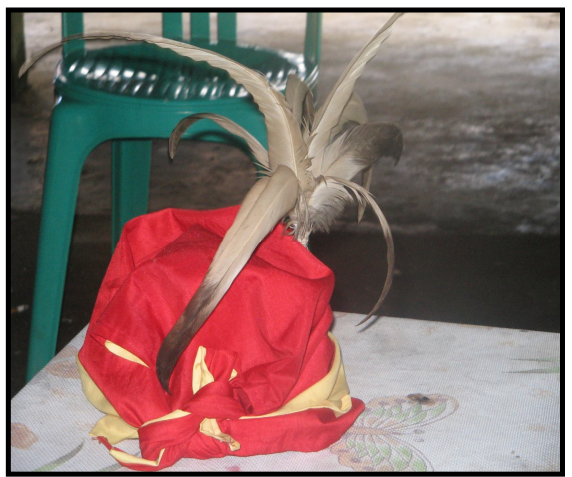

Gambar 7. Ikat kepala yang digunakan pemuda saat upacara adat. Sumber :Mezak Wakim 2007

Dalam upacara legu-legu, laki-laki dan perempuan memakai pakaian berwarna terang, merah dan kuning. Warna-warna merah juga digunakan pada saat upacara perkawinan adat, seperti misalnya di Tobaru. Warna kuning diasosiasikan dengan kesuburan dan keasaan yang berlimpah-limpah (Mursadi, 1980: 388389).

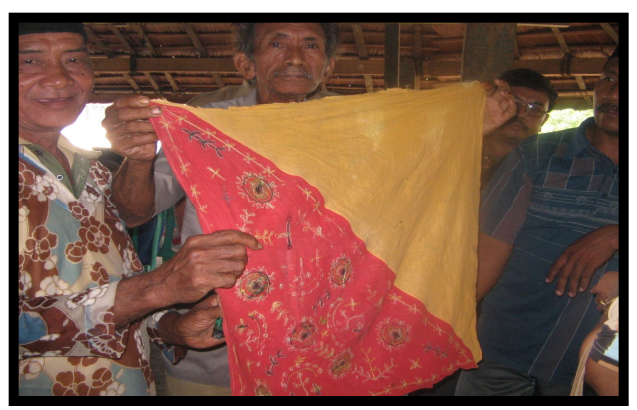

Gambar 8. Ikat kepala yang dipergunakan kaum perempuan pada saat upacara adat. Sumber: Mezak Wakim 2007

Fungsi sasadu, selain digunakan untuk berbagai kegiatan yang bersifat keagamaan, juga dipakai untuk berbagai kegiatan sosial biasa. Fungsi sasadu berubah menjadi balai desa apabila di desa dilangsungkan pertemuan-pertemuan umum, misalnya untuk membicarakan masalah pertanian sehubungan dengan masa tanam yang akan datang. Dulu pemuka-pemuka desa menyelesaikan sengketa adat di rumah sasadu. Setelah 
orang-orang desa sekarang tinggal secara permanen di desa dan sudah mempunyai rumah-rumah yang bagus, penyelesaian adat di desa sekarang dilangsungkan di rumah nyira atau kepala desa, atau di rumah salah satu pihak yang bersengketa.

Untuk perkawinan yang dilangsungkan menurut aturan-aturan adat maka pelaksanaannya tidak diadakan di $s a s a d u$, tetapi di kantor Catatan Sipil dan Gereja. Perayaannya kemudian diadakan di halaman depan rumah yang diberi tenda atau atap seng sementara, disebut sabua.

Di Sahu, sasadu kebanyakan digunakan untuk upacara-upacara yang berhubungan dengan kegiatan pertanian, seperti misalnya setelah menabur benih biasanya dilangsungkan suatu upacara yang disebut sa'ai lamo'o, masak besar atau ngorom lamo'o, makan besar. Di Kecamatan Sahu dan terutama di pedalaman, pertanian padi ladang lebih penting daripada tempat lainnya. Pengolahan ladang tiap tahunnya ditutup dan dibuka dengan suatu upacara yang dalam bahasa Melayu Maluku disebut makanmakan sabua, dan berlangsung selama 3 hari 3 malam. Menurut tradisi sebenarnya upacara tersebut lebih kompleks, yaitu dengan didahului oleh suatu ritual yang disebut walenge, di mana seorang dukun (gomatere) yang melakukannya mencoba berhubungan dengan roh orang-orang yang telah meninggal. Sekarang ritual ini sudah tidak pernah diselenggarakan lagi semenjak pemerintah melarangnya pada pertengahan tahun 1960-an. Kalau dulu upacara makanmakan sabua dilangsungkan berhari-hari menurut jumlah daun atap pada sasadu yaitu 9 hari, namun sekarang upacara tersebut tidak boleh berlangsung lebih dari 3 hari. Perbedaan-perbedaan tradisional antara desadesa, yang penting dalam segi kebudayaan, cenderung memudar sekarang (Mursadi: 1980).

\section{Ragam Hias}

Ragam hias pada bangunan sasadu di Desa Taraudu ditemukan berbagai ukiran yang dipahat maupun dilukis pada 8 tiang-tiang utama (ngasu ulamo) dan 12 tiang teritis (ngaso u audo) antara lain: daun, bunga, manusia, ular, kurakura dan lain-lain yang melambangkan kepercayaan pada agama suku mereka dan sampai sekarang setelah tahun 1980an sudah dilarang kurang lagi dipercaya oleh mereka. Namu ada beberapa tokoh adat yang mengatakan bahwa ini tidak mengandung makna hanya hiasan untuk memperindah bangunan sasadu tersebut. Namun menurut salah satu tokoh masyarakat dan sesepuh orang Taraudu, gambar pada ragam hias memiliki makna historis dan religius-magis.

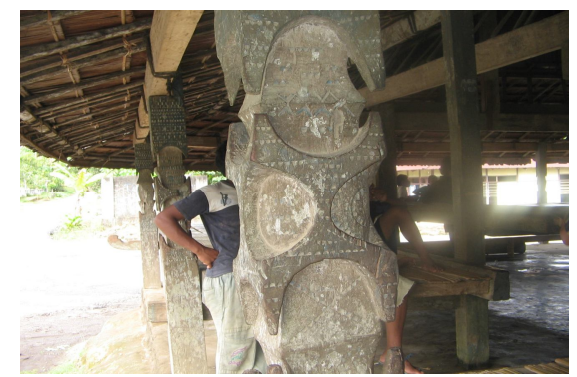

Gambar 9. Salah satu bentuk ragam hias pada tiang penyangga sasadu

Sumber: Mezak Wakim 2007

\section{a. Flora}

Daun gadihu digunakan pada upacara pernikahan. Saat pengantin masuk rumah, dilakukan acara pencucian kaki pengantin perempuan oleh salah satu anggota keluarga pihak laki-laki dengan cara mencelupkan daun gadihu ke air yang terdapat di dalam pasu dan dikibaskan pada kaki pengantin perempuan. Menandakan perempuan itu sudah tidak lajang lagi dan resmi telah bersuami dan menyatu dengan keluarga suami serta kerabatnya. Bunga aster yang berwarna putih melambangkan kesucian seorang gadis dan warna kuning melambangkan warna keagungan. Warna ini biasa digunakan oleh orang tua. Anak muda yang belum menikah dilarang menggunakan warna ini. Sedangkan, bunga mawar, melambangkan keharuman. Bunga mawar sulit dipetik. Ini suatu kiasan pada perempuan yang cantik tapi sulit untuk disentuh. Warna biru adalah warna 
yang digunakan oleh perempuan atau lakilaki yang sudah menikah.

\section{b. Fauna}

Ular melambangkan binatang yang cerdik pada saat menghadapi bahaya. Sementara kura-kura adalah hewan yang diam tetapi aktif di saat menghadapi bahaya, seperti mengeluarkan kencing. Air kencing tersebut apabila kena mata mengakibatkan kebutaan.

\section{c. Agama dan Kepercayaan}

Seperti suku bangsa lain di Indonesia sebelum memeluk agama (Katholik, Islam, Kristen), suku Sahu di Jailolo pada umumnya dan Desa Taraudu khususnya adalah anemis, dinamisme, totemisme. Dalam kepercayaan, mereka percaya adanya roh-roh gaib yang menghuni benda-benda, pohon-pohon yang dianggap keramat. Roh-roh itu ada di sekitar manusia dan alam, mengambil bentuk dan wujud berbeda-beda. Roh itu tinggal di gunung, pohon-pohon besar, sungai, batu atau pada hewan tertentu (buaya, kura-kura dan ular). Selain percaya adanya roh-roh, penduduk Taraudu juga percaya adanya kekuatan yang lebih tinggi yaitu Tuhan Allah Yang Mahakuasa, Jou Madutu, seperti di Maluku Tengah Upu Kabasa Upu Lanite Tapele atau Tuhan Allah Yang Mahakuasa, Tuhan langit dan bumi. Ngidu atau tidur adalah suatu proses seseorang mengadakan hubungan dengan roh leluhur atau roh halus yang dapat memberitahu tentang nasib baik atau buruk. Proses ini mulai dari tidur dengan badan ditutup selimut, menggigil atau bergoncang sampai tidur terlelap. Tujuannya adalah untuk mengetahui nasib seseorang ( baik-buruk, hidup atau mati), terutama bagi keluarga mereka yang jauh atau berada di luar daerah Jailolo.

Bangunan sasadu berbentuk perahu, terutama pada bagian puncaknya. Bentuk perahu erat kaitannya dengan pemujaan nenek moyang atau leluhur mereka yang datang dari jauh dengan naik perahu dan juga kepercayaan perahu adalah kendaraan roh (Heekern, 1958: 231).

Layaknya sebuah perahu, masyarakat adalah awak pada perahu tersebut. Ini terdapat juga di Maluku Tenggara di mana perahu sebagai simbol kelautan sekaligus simbol kesuburan sebagai satu keluarga besar di dalam masyarakat.

Masyarakat Taraudu juga mengenal adanya totemisme atau penghayatan adanya makhluk-makhluk atau binatang-binatang tertentu yang mempunyai hubungan khusus dengan kelihaian atau menjadi sesuatu yang sakral, karena dianggap suci. Misalnya ular dianggap hewan cerdik, sedangkan kurakura dianggap hewan yang diam tetapi aktif pada saat diserang oleh musuh. Contohnya saat diserang musuh, kepala dan kaki disembunyikan namun menyemprotkan air kencing ke atas, apabila tidak hati-hati dan kena mata, akan mengakibatkan kebutaan.

Hewan seperti ular dan kura-kura menjadi binatang yang memiliki nilai pendidikan, yakni cerdik dan diam tetapi aktif di saat menghadapi bahaya. Mengenai kepercayaan yang disebutkan di atas hingga kini masih ada. Walaupun juga tidak terlalu nampak lagi oleh karena penduduk Taraudu telah memeluk agama Kristen Protestan. Ada beberapa keluarga tertentu masih mempraktikkannya dalam kehidupan kesehariannya. Hanya lewat ucapan untuk memanggil arwah leluhur pada saat mereka membutuhkan, untuk menjaga anak cucu, baik di Taraudu maupun di luar Taraudu.

\section{Tradisi Mendirikan Sasadu a. Tahap Persiapan}

Pengadaan bahan-bahan ramuan dilakukan setelah pertemuan musyawarah antara raja dan tua-tua adat. Ramuan tersebut terdiri atas: tiang, balok, kasu, bambu, atap dan tali-temali. Jenis kayu yang digunakan adalah gopasa. Jenis-jenis ramuan tersebut dibagikan berdasarkan kelompok organisasi masing-masing soa yang ada. Sebelum pengambilan bahan- 
bahan tersebut, pagi hari (subuh) mereka telah lebih dulu mengadakan sirih pinang di tempat berkumpul. Untuk Desa Taraudu pengambilan ramuan untuk sasadu mempunyai beberapa prasyarat antara lain sebagai berikut: terhadap 8 buah tiang utama yang disebut ngasu u lamo : (1) Parang atau kapak yang telah diasah tajam harus dipendamkan ke dalam debu tungku atau diasapkan di atas para-para dapur; (2) Orang yang menebang pohon tidak boleh makan dan minum (puasa). Pada saat ayunan kapak pertama, kedua dan ketiga, harus memejamkan mata dan tarik nafas secara dalam; dan yang (3) Kayu yang sudah ditebang dibiarkan sampai daunnya berguguran baru dikerjakan untuk dijadikan balok atau tiang.

Pengambilan bahan-bahan di atas disesuaikan dengan perhitungan bulan di langit yaitu 8 malam setelah bulan purnama dan pada saat air surut (meti). Hal itu dipercayai mereka supaya bahan bangunan tidak mudah lapuk atau berbubuk. Hal ini masih tetap berlangsung sampai sekarang baik untuk pembuatan rumah tinggal maupun rumah musyawarah sasadu. Hal ini mungkin berkaitan dengan berkurangnya kadar air pada pohon atau kayu yang diambil, sehingga dapat bertahan lama dari kelapukan.

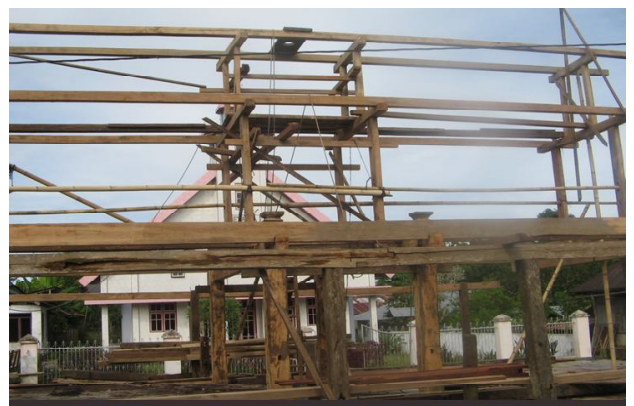

Gambar 10. Konstruksi Rumah Adat Sasadu

Sumber: Penelitian 2007

Selain itu, ada ketentuan lain yang harus dipenuhi pada saat membangun sasadu seperti, pertama: penentuan tempat untuk mendirikan sasadu harus pada lokasi milik desa sendiri dengan cakupan areal yang cukup luas dan sentral; yang kedua: arah bangunan harus timur-barat menurut panjang bangunan (geometris); dan yang ketiga: dalam penentuan ukuran panjang dan lebar harus mengikuti aturan suku Sahu. Satuan ukuran pada zaman dahulu adalah depa, yaitu rentangan dari tangan kiri dan kanan dengan batas ujung jari tengah.Yang perlu diperhatikan unsurunsur dalam pembuatan kerangka rumah musyawarah sasadu harus selalu angka genap 2, 4, 8 dan 12. Namun pada batas ukuran panjang maupun lebar harus ditambah dengan ukuran ganjil $(1,3,5,7$ dan 9). Penambahan ukuran ganjil ini menurut kepercayaan adalah agar kehidupan masyarakat tetap berkesinambungan, berketurunan dan berlimpah rezeki. Dalam kosmologi orang Halmahera, angka genap diasosiasikan dengan laki-laki, sedangkan angka ganjil dengan perempuan, nenek moyang, dan garis keturunan. Bangunan yang benar harus terdiri atas dua unsur tersebut, sebab menurut mereka alam terdiri atas unsur laki-laki dan perempuan.

\section{b. Teknik dan Cara PembuatanBagian Bawah}

Tempat bangunan harus didirikan pada sebidang lahan yang cukup luas dan dibatasi oleh pagar sebagai pengaman, karena semua bahan bangunan diletakkan pada lokasi atau rumah kecil yang disebut walang atau sabua. Denah yang disediakan sebagai lantai bangunan diberi tanda dengan patok-patok kayu. Tempat-tempat letak tiang diberi alas batu yang agak tinggi dan rata permukaannya, agar pada saat ditimbuni tanah lantai bangir, tiangtiang tersebut tetap kelihatan.

Pengalas tiang terdiri atas 8 buah tiang inti ruangan tengah atau ngasu $u$ lamo dan 12 tiang teritis atau ngasu $u$ audo. Setelah bangunan selesai dibangun, barulah lantai ditimbuni tanah dan kemudian dipadatkan sampai rata. Batas denah ditandai dengan susunan batu kali yang diatur sebagai penahan tanah lantai dalam sasadu (bangir), agar lebih tinggi dari tanah bagian luar. Pada ruang bagian 
tengah ini juga dibuat dedegu yang lebih rendah dari tempat duduk raja dan staf pemerintah desa. Tempat duduk (taba) dipasang antartiang dengan bahan dari bambu yang terdiri atas: (1) lamaa ngimon, (2) laman saee dan (3) laman idis, pada kedua ujung denah ruangan. Dewasa ini batu batas dari bangir sudah tak ada lagi, namun fungsi dari sasadu sebagai rumah musyawarah masih dilaksanakan.

\section{Bagian Tengah}

Pada bagian tengah ini tidak berdinding, tetapi terdiri atas tiang-tiang penopang yaitu 8 buah tiang ruang tengah dan 12 tiang teritis seperti yang telah disebutkan terdahulu. Menurut informasi dari tua-tua adat, tiang-tiang penopang haruslah dibuat oleh tukang yang ditunjuk oleh para tua adat. Pada umumnya teknik pekerjaan tiangtiang ini berbentuk empat persegi. Tiang tengah yang terdiri atas 8 buah, ukurannya lebih besar sebagai pemikul atau penahan konstruksi bangunan atas. Dengan demikian, pada bagian atas dari bangunan diberi lubang untuk pemasangan balok dingasu melintang sebagai dasar tumpuan 2 buah tiang konstruksi atas sesera. Sistem pembuatan tiang teritis dikerjakan dengan teknis kep, sebagai pemikul balok teritis (gambar cara pemasangan konstruksi bangunan sasadu).

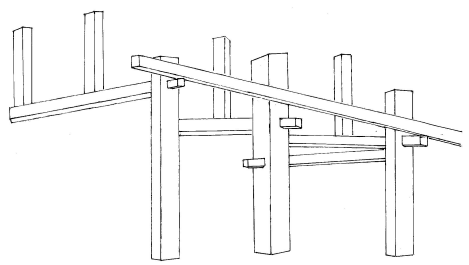

Gambar 11. Cara pemasangan konstruksi bangunan sasadu.

Sumber: Penelitian 2007

Selain dari 8 tiang (ngasu u lamo) dan 12 tiang (ngasu u audu), terdapat pula tiang-tiang tambahan sebagai penyangga balok yang diletakkan antara ngasu u lamo dan ngasu $u$ audu. Fungsinya sebagai tiang-tiang penyangga balok untuk konstruksi bagian atas, sekaligus sebagai penyangga degu-degu (taba).

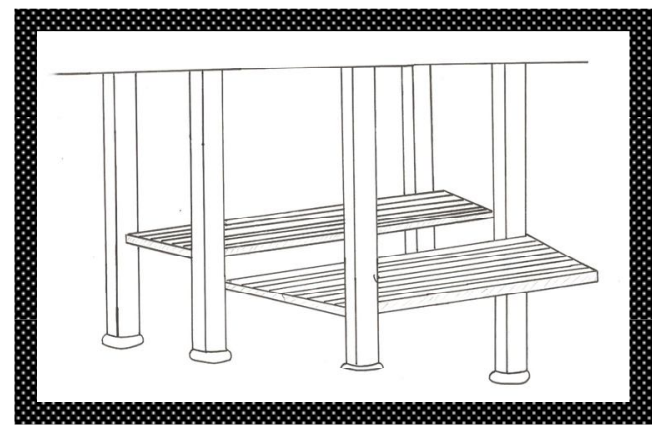

Gambar 12. Degu-degu dengan Tiang Penyangganya

Sumber : Penelitian 2007

\section{Bagian A tas}

Pada

musyawarah sasadu tidak berloteng. Konstruksi bangunan atas dikerjakan dengan sistem pasak dan kep. Bangunan bagian atas terhitung dari 4 buah balok (dingasu) yang memikul 8 buah tiang sisera, dan 8 buah tiang sisera sebagai penopang 4 buah balok (baal tala). Fungsi baal tala sebagai pemikul tiang nok (ngasu $u$ olan) yang berjumlah 4 buah, selanjutnya dipasang 2 balok yang melintang di atas memikul balok-balok yang memanjang untuk dipasang kasu-kasu sebagai rangka pengikat atap. Puncak dari tiang nok (ngasu u olan), diletakkan balok bubungan (wanat), yang dipahat hiasan haluan dan buritan dari sebuah perahu yang disebut kalulu .

Pemasangan rangka kasu totara mempunyai jarak antara 50-60 cm disesuaikan dengan panjang atap. Atap sasadu dibuat dari daun sagu dan panjangnya dihitung menurut jumlah daun atap (warasa) yang sudah digariskan oleh adat. Sasadu di Desa Taraudu panjangnya 9 warasa, di Desa Gamnial dan Awer masing-masing lima dan tujuh warasa. Jumlah daun atap ini berkaitan dengan lamanya upacara panen tahunan yang akan diselenggarakan.

Sistem pemasangan atap dimulai dari sebelah kiri ke kanan terdiri atas 4 susunan, jarak antarsatu atap dengan atap 
yang lain disebut malagon atau duga. Susunan atap bagian muka dan belakang terdiri atas 7 susunan atau wartunding, yang disusun melebar dari bawah dan menyudut pada bagian atas menyerupai ekor udang (buromakiki).Perlu dijelaskan, bahwa penutupan atap teritis dan bubungan dilapisi 2 lirang atap. Pada ujung kasu rangka atap bagian bawah atap teritis ditutup dengan belahan batang nira atau nibong yang berfungsi sebagai lisplang (raom). Semua ikatan atap digunakan tali bambu (loleba) dan pengikat rangka atap kasu dengan tali ijuk dan susunan atap yang menutupi bagian dari haluan dan buritan (simbol perahu) yang berbentuk segi tiga disebut bada $a$.

Hal yang menarik dari ikatan-ikatan ini, ialah terdapat pada belahan batang enau yang diikat pada bagian bawah kasu rangka atap di belakang lisplang. Ikatan ini dimulai dari ujung pintu depan rumah sasadu dan berakhir pada tempat semula, tanpa ada sambungan. Menurut mereka, (orang Taraudu ) ikatan ini sebagai simbol persekutuan atau kerukunan hidup masyarakat yang tetap berkesinambungan, berketurunan dan berlimpah rezeki.

Pada waktu kunjungan di lapangan (2007), atap sasadu sebagian sudah diubah dengan seng dan beberapa tiang mengalami pengecatan yang kurang teratur dan tidak memiliki nilai historis maupun religi. Dikhawatirkan nilai dan makna dari arsitektur tradisional ini hilang, terutama generasi muda. Dengan demikian, hilang juga identitas dan jati diri masyarakat pendukungnya.

\section{Tenaga Pelaksana}

Untuk mendirikan tempat musyawarah sasadu ditunjuk seorang tukang yang dibantu oleh tua-tua adat dan masyarakat setempat. Pelaksanaan pembuatan sasadu dilakukan oleh masyarakat secara gotong-royong. Pembagian kelompok kerja disesuaikan dengan adat atau kelompok sosial masyarakat. Kelompok sosial masingmasing bertanggung jawab atas bagian tertentu dari sasadu itu antara lain: marga Walasae bertanggung jawab terhadap bubungan atap, yang harus ditutup dengan serat ijuk dari pohon aren/enau; pengukiran dan penempatan ukiran pada tiang-tiang serta pembuatan meja-meja (tabe atau lame) serta bangku-bangku (dedegu ) merupakan tugas dari anggota kelompok Ngowarepe. Menurut mitos setempat, mereka adalah keturunan dari kakak nenek moyang kelompok Walasae. Kelompok Walangatom, mempunyai tugas mengikat atap (gusuong).

Dengan demikian dapat disimpulkan bahwa bangunan tempat musyawarah sasadu melambangkan sistem kekerabatan, struktur masyarakat, organisasai sosial dan pola hubungan serta fungsi kelompok masyarakat, sesuai dengan adat yang berlaku pada masyarakat tersebut. Di samping itu nampak pula ideologi, pandangan hidup, serta makna nilai-nilai demokratis, persatuan, kebersamaan demi keberlanjutan hidup mereka kini maupun yang akan datang.

\section{PEN UTUP}

Rumah musyawarah sasadu merupakan salah satu bentuk budaya orang Sahu yang menggambarkan kosmologi dari keseluruhan budaya orang Sahu (Taraudu). Melalui bentuk arstitektur, makna rumah musyawarah dapat dipelajari eksistensi, pandangan hidup dan sistem nilai budaya orang Taraudu sebagai suatu masyarakat adat.

Dilihat secara fisik, sasadu mengalami perubahan terutama pada bagian atas atap rumah. Ada pergantian dari atap rumbia dengan seng. Dengan masuknya pengaruh modernisasi maka upacara adat panen padi mengalami perubahan yang biasanya dilakukan selama sembilan hari sesuai dengan tata adat setempat, mengalami perubahan menjadi tiga hari saja. Dengan demikian terjadi pergeseran nilai dan tata upacara adat. Sebenarnya pergeseran ini disinyalir oleh masyarakat karena masuknya bangsa Barat dengan agama 
Kristennya. Dalam perkembangannya, telah mengikis fungsi dan peranan rumah musyawarah sasadu terutama praktik adat tertentu, seperti penyembahan kepada supernatural. Terjadi persaingan rohani antaragama Kristen dan kepercayaan agama asli yang berakibat pada terkikisnya adat. Pada upacaraupacara adat masa kini sudah jarang dilakukan ritual penyembahan kepada leluhur dan kekuatan-kekuatan supernatural. Namun pada saat tertentu, masih ada pemanggilan terhadap roh-roh leluhur untuk menjaga anak cucu atau keturunan mereka di mana saja mereka berada.

Di lain pihak, ada kemauan dari masyarakat setempat untuk tetap mempertahankan arsitektur rumah sasadu ini. Terutama dalam usaha merenovasi, agar dapat mengangkat kembali spirit atau konsepsi-konsepsi yang memiliki nilai positif dalam adat orang di Taraudu. Mereka berharap hal tersebut tetap dipertahankan agar tidak hilang jati diri sebagai orang Sahu, terutama bagi generasi mudanya. Agar dapat direvitalisasi dan digunakan untuk pengembangan masyarakat Sahu terutama Desa Taraudu. Ragam hias pada bentuk bangunan tradisional dapat memperlihatkan eksistensi bangunan. Misalnya sasadu merupakan mikrokosmos, representasi dari sebuah desa. Rumah tempat musyawarah dan upacara adat panen padi (waleng). Di tempat tersebut dapat dihadirkan leluhur apabila dibutuhkan untuk keperluan upacara-upacara tertentu. Atap yang berjumlah sembilan merupakan acara pesta perayaan panen selama sembilan hari. Bangunan ini berbentuk perahu, terutama pada bagian puncak sasadu. Bentuk perahu erat kaitannya dengan pemujaan nenek moyang atau leluhur mereka yang datang dari jauh dengan naik perahu. Mereka percaya bahwa perahu adalah kendaraan roh.

\section{DAFTAR SUMBER}

\section{Makalah dan Laporan Penelitian}

Puewersti, Nadia. 2007.

Penelitian Arsitektur pada Bangunan Tradisional, Pusat Dokumentasi Arsitektur.

Soselisa.H.L, et al . 2006. Laporan Penelitian : Rumah Adat Suku Oirata di Pulau Kisar ; Proyek Pemanfaatan Kebudayaan Daerah Maluku. Balai Kajian Sejarah dan Nilai Tradisional Provinsi Maluku dan Maluku Utara Ambon.

Soroto Myrtha. 2003.

Dari Arsitektur Tradisional Menuju Arstitektur Indonesia., Ghalia Indonesia.

Suantika.I.Wayan, 2005. Makalah Konsep Dasar Arsitektur Tradisional Daerah Maluku.

Yulianto Sumalyo. 1998. Makalah Pelestarian Arsitektur Tradisional Indonesia dalam Jaman Modern pada Seminar Apresiasi Arsitektrur Daerah Maluku. Dinas PU Tingkat I Provinsi Maluku, Ambon.

\section{Buku}

Abdulrahman Yusuf. 1998.

Beberapa Catatan Bangunan Tradisonal Kawasan Utara Provinsi Maluku, Lembaga Kebudayaan Daerah Maluku Kie Raha Ternate.

Adhi Mursid \& Leontien, E. 1987.

Visser Sasadu atau Rumah Adat di Sahu, Halmahera Utara,

Dalam Buku, Halmahera dan Raja Ampat Sebagai Kesatuan Majemuk, LEKN LIPI Jakarta.

Heekern, H.R.Van. 1958.

The Bronze-Iron Age Of Indonesia. S Gravenhage Martinus Nijhoff.

Jonge de Nico \& Toos van Dijk. 1995.

Forgotten Islands of Indonesia, The Art and Culture of the Southeast Moluccas, Periplus Edition, Singapore.

Joseph.L.C. 1982.

Aspek Arsitektur Tradisional Daerah Maluku. Proyek Inventarisasi Dokumentasi Kebudayaan Daerah, 
Departemen Pendidikan dan Kebudayaan Provinsi Maluku.

Joseph.L.C,\& Frans Rijoli. 2005.

Aspek Arsitektur Tradisional Daerah Maluku, Dalam Buku Maluku Menyambut Masa Depan. Lembaga Kebudayaan Daerah Maluku.

Koentjaraningrat. 1958.

Metode-Metode Antropologi dalam Penelitian, Penyelidikan Masyarakat dan Kebudayaan Indonesia. Penerbit Universitas Indonesia, Jakarta.

2002.

Manusia dan Kebudayaan. Djambatan: Cetakan ke-19, Jakarta.

Lembaga Kebudayaan Daerah Maluku. 2005. Laporan Kegiatan Semiloka Arsitektur Tradisional Daerah Maluku.

Masinambow .E.K.M. (Ed). 1983.

"Halmahera dan Raja Ampat Sebagai Kesatuan Majemuk". Buletin LEKNAS LIPI, Jakarta.

\section{Sumber Lisan/Informan}

Agustinus Dansa 50 tahun Kepala Desa Taraudu. Alamat Desa Taraudu Kecamatan Sahu Kabupaten Halmahera Barat.

Daniel Ronga 60 tahun Kepala Soa taraudu, Alamat Desa Taraudu Kecamatan Sahu Kabupaten Halmahera Barat.

Demian Trigmon Tokoh Masyarakat Taraudu, Alamat Desa Taraudu Kecamatan Sahu Kabupaten Halmahera Barat.

Klemon Loee 80 tahun, tokoh adat, alamat desa Taraudu, Kecamatan Sahu Kabupaten Halmahera Barat.

Martinus Mess 70 tahun, tokoh adat, alamat Desa Taraudu, Kecamatan Sahu Kabupaten Halmahera Barat.

Harun Betal 80 tahun tokoh adat alamat Desa Taraudu Kecamatan Sahu Kabupaten Halmahera Barat. 